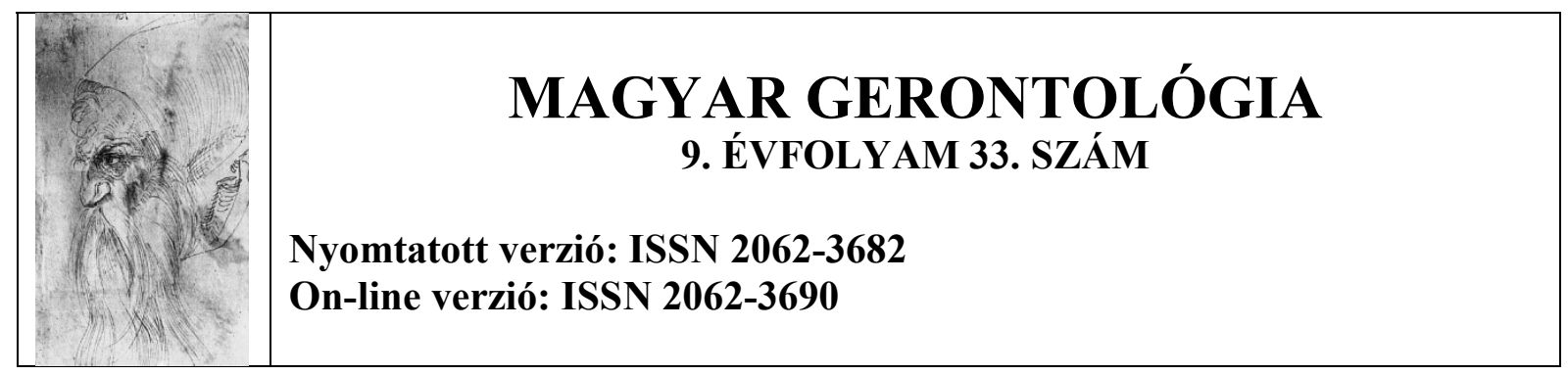

\title{
CSALÁDI (INFORMÁLIS) GONDOZÁST SEGÍTŐ RENDSZEREK MAGYARORSZÁGON
}

\section{Patyán László}

\section{Összefoglaló}

A demográfiai öregedés kihívásaival az Európai Unió minden tagállamának szembe kell néznie. Ha a tagállamok demográfiai jellemzőit tekintjük, látható, hogy nincsenek lényegi eltérések sem az időskorúak jelenlegi arányában, sem pedig e ráták várható jövőbeni alakulásában. A demográfiai és társadalmi öregedés a jóléti rezsimek több területét is érinti, de ezek közül általában az egészségügyi és nyugdíjrendszert és a személyes szolgáltatásokat szokták a középpontba helyezni. A tanulmány a személyes szolgáltatások egy speciális területével foglakozik, mely ma a legtöbb posztkommunista országban éppoly új, mint amilyen régi: ez a család által végzett gondozás s ennek támogatása.

A tanulmány kitér a családi gondozók támogatásával kapcsolatos jóléti politikák ismertetésére, megvizsgálja a tagállamok gondozási politikájának rendszerezési kísérleteit, elemzi a közelmúltbeli és jelenleg érzékelhető gondozáspolitikai folyamatokat, ideológiákat, s végül kitér a volt kommunista országok sajátságos helyzetére, majd bemutatja Magyarország a családi gondozással kapcsolatos gondozáspolitikáját. Az esszé alapgondolata, hogy a demográfiai kihívások ugyan hasonlók, de a szolgáltatás politika, az intézményi rendszerek fejlettsége komoly eltéréseket mutat országonként. Az országok fejletlen intézményes szolgáltató rendszerei mellett a gondozó családtagokat támogató eszközöknek pedig igencsak híján vannak a posztkommunista tagállamok. 


\section{Summary}

\section{Family (Informal) Caregiver's Support Systems in Hungary}

The member states of the European Union have to face the challenge of demographic aging. Taking the demographic characteristics of the member states, there are no essential differences in either the current or in the expected future development of the proportion of elderly people. Ageing affects several areas of the welfare regimes, but it is usually the health and pension systems and personal services that are highlighted. This paper deals with a special area of personal services, the family (informal) care and the support of carers in Hungary.

The study introduces definitions of the informal care, welfare policies on family caregivers, the systematization attempts of the care policy in the member states, it analyzes the recent past and currently perceived care policy processes and ideologies, and finally describes the specific situation in the former Communist countries through an example of a Hungarian care policy. The basic idea of the article is that although the demographic challenges are similar, but the service policy and the development of the institutional systems show significant differences in each country. In addition to the underdeveloped institutional service system in the different countries, the post-Communist countries lack the supporting tools of the caring family members.

\section{Családi (informális) gondozás fogalomrendszere}

A családtagok, rokonok, ismerősök által végzett idősgondozási tevékenységet igen sokféleképpen szokták értelmezni. Abban minden időspolitikával foglalkozó nemzetközi szervezet egyetért azonban, hogy az öregedés jóléti rendszerekre nehezedő terhei mellett fontos erőforrásként kell kezelni a család gondozói tevékenységét.

Miért nehéz értelmezni a családi gondozás jelenségét és miért oly nehéz támogató jóléti eszközökkel segíteni a családtagokat szerepük ellátásában?

E kérdések válaszait az informális gondozás fogalomrendszerének, természetének elemzésén keresztül közelítjük meg, majd később megvizsgáljuk az európai gondozási rezsimeket is, láthatóvá téve a gondozási rendszerek prioritásait.

A legtöbb fogalom az informális gondozás jelenségének leírására vállalkozik, s ezen jellemzők szerint értelmezi magát a fogalomrendszert is. A fő jellemzők a következők:

- Az informális gondozás szolidarisztikus, nem fizetett tevékenység, azaz a gondozó és gondozott közötti érzelmi kapcsolaton alapszik. Egyes megközelítések inkább a 
családtagok gondozói szerepét emelik ki, míg mások hangsúlyozzák a közösségi kapcsolatok szerepét is (szomszédság, barátok) (Hajek - König, 2015).

- A tevékenység jellege szerint is különbséget tehetnek a gondozás formái között. A legtöbb kutatás, mely a családi gondozás mértékét és társadalmi hasznát vizsgálja, a gondozás jellegét a fizikai feladatok ellátására korlátozza, mely az időskorú önellátásához szükséges mindennapi tevékenységekben nyújtott segítséget jelenti (ADL, IADL funkciók) (Hiel, 2015). Mások, melyek a gondozó és gondozott érzelmi kapcsolatát és a gondozók terheit kutatják, kiegészítik ezt a lelki gondozás, a közös időtöltés tevékenységeivel, melyet sok esetben a formális gondozási formák nem is tudnak helyettesíteni.

- A tevékenység intenzitása szerinti kategóriák a családtag által végzett gondozási munka időtartamát, valamint az ezzel járó terheket helyezik a vizsgálat középpontjába (OECD, 2011)

Hazánkban nincsen egységes fogalom az idősek informális gondozására, és mint látni fogjuk, nem találunk jól működő támogatási rendszert sem e csoport segítésére. A korábbi támogatási formák (ápolási díj) gyakorlata szerint azonban a családi gondozást aktív korú személy végzi, aki szüleit, vagy közeli hozzátartozóját gondozza. A gondozás intenzitása tekintetében pedig napi 4 órát, vagy ennél több időt fordít családtagja ellátására. Legalábbis így határozhattuk volna meg a tevékenység kereteit 2014-ig.

\section{A családi (informális) gondozást támogató politikák nehézségei}

A családi gondozást támogató rendszereknek, stratégiáknak számos nehézséggel kell szembenézniük.

- Egyes vélekedések a családi gondozás szolidarisztikus jellemzőjét emelik ki. E fordításban tehát a tevékenység alapvető családi kötelesség, melyet nem kell intézményes eszközökkel befolyásolni, mivel ez így szép és természetes. Az érvelés azért hibás, mert a hazánkban igen fejlett a gyermeket nevelő családtámogatási rendszert ilyen alapon szintén górcső alá lehetne venni. A gyermekek nevelése csakúgy családi feladat, mint amilyen az idősek gondozása lehet.

- Mások a viták középpontjába a gondozás - és általában a családi tevékenységek gender - jellegü megközelítését helyezik. A családtagok gondozását közismerten többségében nők végzik, így a tevékenység támogatása a nők otthonmaradásához, munkaerőpiacról való kiszorulásához vezethet ezzel növelve a nők kiszolgáltatottságát a kenyérkereső 
férfivel szemben. A nők gondozási és háztartási feladatoktól való felszabadítása tehát a feminista irányzatok szerint növeli önállóságukat és függetlenségüket. Megjegyzendő azonban, hogy a megközelítés szélsőséges értelmezése megfosztja a nőket (és férfiakat) attól, hogy szeretteiket otthon gondozzák, még akkor is, ha ezt maguk így akarják, arról nem beszélve, hogy a gondozók nagy része már nem aktív a munkaerőpiacon, maga is időskorú és egy háztartásban él azzal a hozzátartozóval, akit gondoz.

- Az Európai Unió által is deklarált foglalkoztatást középpontba helyező politikák (workfare) sem nézik jó szemmel az aktív korúak otthonmaradásra kárhoztatását ezért kifejezetten ellenzik, vagy csak nagyon rövid időszakokra támogatják az időskorú családi gondozását.

- További probléma, hogy a családi gondozók általában véve sem alkotnak egy homogén csoportot, nem határozzák meg magukat gondozó családtagként, leterheltek, kevés szociális kapcsolattal rendelkeznek, mivel a gondozás gyakran izolálja öket. E gondozók nem értelmezik magukat „gondozó családtagnak”. Tevékenységüket sok esetben kizárólagosan, egyedül végzik, kevés információjuk van a támogató rendszerekről így aztán nem kérnek segítséget sem. Ha mégis kapcsolatba kerülnek a formális ellátórendszerrel, gyakran elutasítóak, mivel úgy érzik, hogy az általuk végzett fontos tevékenységet akarja a szakember kivenni a kezükből. Ebben nyilván nagy szerepet játszik a formális rendszerek gondozó családtagokkal kapcsolatos attitüdje, illetve az erre vonatkozó szakmai protokolljuk is.

\section{Miért erősödik a családi gondozás jelentősége? Európa demográfiai öregedésének következményei}

Az Eurostat 2016 évben publikált adatai ${ }^{1}$ szerint 2005-ben 16,6\% volt a 65 év feletti populáció aránya az Európai Unióban, s ez a ráta 18,9\%-ra nőtt 2015-re. A lengyel idősek aránya 2,3 százalékkal, a magyaroké szintén egészen pontosan ennyivel emelkedett. Az idős népesség számbeli emelkedése mellett kiemelkedő az igen idős népesség számbeli arányának emelkedése is. 2015-ben az Unió népességének 5,3\%-a volt 80 év feletti, ez az arány Bulgáriában 4,6\%, Észtországban 5, Lengyelországban 4, Magyarországon 4,2\% volt.

Hasonló tendenciák látszanak az OOSR (Oldest Old Suppor Ratio) adatiban is. ${ }^{2}$ A ráta 195 ország adatait elemezve 75,7 volt 1950-ben, 2005-re már 32-re csökkent, s becslések szerint

\footnotetext{
${ }^{1} \mathrm{http}$ ://ec.europa.eu/eurostat/statistics-explained/index.php/Population_structure_and_ageing

${ }^{2} \mathrm{Az}$ 50-74 éves népesség aránya a 85 felettihez.
} 
2050-ig további csökkenés várható, elérve akár a 12,5-ös értéket is (Hermann és mtsai, 2010). A fejlett jóléti rendszerekkel rendelkező államokban azonban már 2010-ben is 10 - 13 körüli volt a ráta értéke (Tyen, 2010).

Az idősek növekvő aránya egyben azt is jelenti, hogy egyre több ember és egyre tovább él olyan életet mely során életminősége megőrzéséhez tartósan szüksége lesz valamilyen szintü gondozásra. Becslések szerint minden második 65 év feletti igényel valamilyen segítséget a napi tevékenységei fenntartásához, és a gondozásra szoruló európai lakosok száma 2060-ra meghaladja a 40 millió főt (Carretero és mtsai, 2012). A gondozás jellemző részét pedig még mindig a családtagok végzik. Az OECD 2011 évi jelentése szerint a családok gondozó szerepére sokkal nagyobb figyelmet kell fordítani. A jelentés szerint minden tízedik ember gondoz valakit, az ötven év feletti népesség esetében pedig minden harmadik ember végez gongozást. A gondozók jellemző többsége nő, a gondozott személy társa, vagy gyermeke.

A gondozási tevékenység intenzitása, valamint a gondozottal való együtt - vagy különélés szempontjai szerint szokták a gondozóra jutó terheket jellemezni (Carretero és mtsai, 2012),(Lamura és mtsai, 2008). Az OECD a heti 20 vagy annál magasabb óraszámban végzett gondozást intenzív gondozói tevékenységnek minősíti. A 2011 évi adatok szerint (OECD, 2011) a Cseh és a Lengyel gondozók 30\%-a végez ilyen intenzív gondozói tevékenységet.

A családi gondozás elsődlegessége mellett semmiképp nem szabad megkerülni az intézményes szolgáltatások fejlettségének és minőségének problematikáját. Kétségtelen tény, hogy a poszt kommunista országok igen alacsony színvonalon, korlátozott hozzáférés mellett biztosítanak formális szolgáltatásokat az idősek számára. E szolgáltatások többnyire a tartós bentlakásos gondozást helyezik a gondozás középpontjába, s a féröhelyadatok ismeretében az időskorúaknak csak kis része részesülhet ilyen ellátásban. ${ }^{3}$

\section{Gondozási rezsimek és a családi gondozás támogatása}

Európa gondozási profiljának megrajzolása segíthet megérteni a gondozás biztosításának főbb jellemzőit, fejlesztésének lehetséges irányzatait. Mielőtt azonban a gondozási rezsimek felvázolásába kezdenénk fontos tisztázni, hogy milyen jóléti rezsimek alakultak ki a posztkommunista országokban a rendszerváltások után? A jóléti rezsimek tipologizálásával foglalkozók közül leggyakrabban Gosta Esping Andresen (1990) nevét szokták kiemelni, aki neves mủvében kísérletet tett a jóléti államok egyfajta rendszerezésére. A három modell - a

\footnotetext{
${ }^{3}$ Megjegyzendő azonban, hogy a posztkommunista országok közül hazánk rendelkezik a legjobb hozzáférési rátákkal a hosszú tartamú gondozást biztosító intézményi férőhelyek arányát tekintve (Eurostat, 2016.)
} 
szociáldemokrata, a konzervatív és a liberális - megkülönböztetésének meghatározó eleme a dekommodifikáció mértéke, azaz, hogy az egyén mennyire válhat függetlenné a piactól az állam jóléti intézkedései eredményeképpen. Andresen megközelítését számos kritika érte, pl. a dél európai államok kifelejtése, a poszt kommunista országok említésének hiánya, de még olyan fejlett jóléti politikával rendelkező országok sem voltak egyértelmüen tipologizálhatók, mint Hollandia. Mások azért kritizálták e tipológiát, mert nem volt érzékeny a gondozás, mint szociális szolgáltatás kérdéskörére.

A poszkommunista országok jóléti politikájával kapcsolatban több helyütt az arcnélküliség, a megkésettség, a „hibrid jelleg” jelzőkkel találkozhatunk. A magyar jóléti politika elemzői olyan rezsimet vizionálnak, melyekre erős hatást gyakorol az aktuálpolitika és több jóléti politika irányelvei keveredve jelennek meg bennük sajátosan elegyedve a történelmi múlt társadalmi hagyatékaival (Tausz, 2006).

A tipológia alkotás nehézségei ellenére Giovanni Lamura és munkatársai (2007) tettek kísérletet az európai gondozási rezsimek meghatározására. A gondozás formális rendszerei és az informális gondozás támogatásának fejlettsége, a gondozás szükségessége, valamint az informális gondozás iránti igény szerint négy fő típust különítettek el.

A care mix típusú államokban relatíve fejlett intézményes ellátások vannak, e mellett különböző módszerekkel az otthoni, informális gondozás, valamint a megvásárolt, vagy migráns gondozás is támogatott. E kategóriába sorolják Németországot, Ausztriát, vagy Franciaországot. Ezen országokban a rendszer több csatornásan finanszírozott (állami támogatások, gondozási biztosítás, gondozott és családtagjai hozzájárulása), de a vegyes rendszer alapja a gondozási támogatás (cash-for-care), melyet a gondozás szükségessége esetén maga a gondozott kap a gondozási szükséglete szerint.

Az univerzális modell államai (Finnország, Svédország, Norvégia) esetében a gondozási rezsim alapja a jóléti szolgáltatások magas színvonalú biztosítása minden állampolgár számára. Az intézményes szolgáltatások magas színvonalúak, s mellette az egyén otthoni ellátását is számos módon támogatják. Ezen országok a családi gondozást magas színvonalú támogató szolgáltatásokkal egészítik ki. Gyakorlatilag itt találjuk a legmagasabb színvonalú családi gondozó támogatási rendszert. A családi gondozást információs technológiai eszközök alkalmazásával, speciálisan erre képzett szakemberek bevonásával segítik és különös figyelmet fordítanak az olyan területekre, ahol a formális ellátások nem szervezhetők meg az elvárt színvonalon.

A family based modell jellemzően a dél európai országokra jellemző (pl. Olaszország, Spanyolország, Görögország). Alapja a család (nők) hagyományos idősgondozó szerepe, így a 
formális intézményi szolgáltatások száma alacsony, nehezen hozzáférhető. A gondozás támogatása általában széles körben hozzáférhető, de alacsony gondozási támogatásokkal valósul meg. Ennek kockázata az idősek és az őket gondozók magasabb szegénységi rátája, míg a tehetősebbek körében szintén jellemző a migráns gondozás preferálása.

A negyedik kategória a korábban említett átmeneti. Ide jellemzően a volt szocialista országokat sorolták (Bulgária, Csehország, Észtország, Litvánia, Románia, Magyarország, Lengyelország). Az államokat magas gondozási igény, és alacsony színvonalú, fejletlen formális ellátás jellemzi ezért az informális gondozás iránti igény magas. Lamura épp ebben látja az átmeneti országok problémáját, mivel az informális gondozás támogatására csak igen kis erőfeszítéseket tesznek e tagállamok. A modell újragondolói (Nies, 2013), (Kraus, 2011) a formális és informális gondozási rendszerek fejlettsége, a támogatások mértéke, valamint a köz és magánfinanszírozás mértéke szerint állítottak fel az eredetitől kissé eltérő klasztereket. Az informális gondozás alacsony szintű támogatásában azonban e szerzők is egyetértettek sőt Kraus ezt tekintette az átmeneti országok egyik fö jellemzőjének. Más szerzők a poszt kommunista országok gondozási modelljét kifejezetten családi alapúnak (familialist) tekintik (Bouget és mtsai, 2016). Az ellentmondás a fent említett tipológiák között azonban csak látszólagos, mivel e modell szerint a támogató rendszerek fejletlensége mellett az idős csak a család gondozói szerepére támaszkodhat. Bouget és munkatársai (2016) a gondozási rezsimek családtámogató funkcióit vizsgálták s ez alapján karakterizálták az országokat. Három kategóriát alkottak. A fejlett gondozási és családtámogatási rendszerekkel rendelkező országok között nem találunk kelet európait. A következő kategóriába azok tartoztak, ahol az ellátások a gondozásra szoruló idősnek járnak. Ide tartozott Szlovákia és Románia. A harmadik kategóriába a fejletlen támogatási rendszerek tartoztak. Ide többek közt Magyarország, Litvánia, Latvia, Macedónia és Lengyelország tartozott.

A szerzők megjegyzik, hogy sok országban a támogatások és programok erősen függenek az uniós támogatásoktól.

\section{Gondozáspolitikák}

E fejezetben igyekszem felvázolni a gondozással kapcsolatos főbb szakpolitikai diskurzusokat, valamint ezek hatását a családi gondozásra. 
- De-familisation ${ }^{4}$ és a gondozást áruként megközelítő politikák (Hoffmann és mtsai, 2013) (Pfau-Effinger, 2014) jellemzően a fejlett jóléti államok gondozáspolitikai eszközeként jelenik meg a témával kapcsolatos írásokban. A család gondozó szerepének csökkentése egyrészt a gondozás gender megközelítéséböl fakadt - azaz esélyt ad a nőknek a munkaerőpiacon való egyenlő részvételre a gondozás helyett, másrészt erősítette a jóléti államok szolgáltató, univerzalisztikus szerepvállalását (pl. a skandináv államokban) (Andresen, 1999). A gondozás piaci áruvá válása (commodifikáció) jellemzően a cash-for-care ${ }^{5}$ rendszerekben erősödött meg. Az elv szerint így erősíteni lehet a szolgáltatók közötti versenyt úgy, mintha az piaci jellegű lenne (new public management), másrészt deklarálni lehet az időskorú jogát ahhoz, hogy maga döntse el, milyen szolgáltatást venne igénybe és kitől, harmadrészt pedig az otthoni munkát megfizethető tevékenységgé lehet tenni, azaz csökkenhet az a trend amikor az állam támogatás nélkül tolja a gondozás felelősségét a családi gondozóra. Ezt a területet, melyet Anttonen (2003) „,cottage industry”“nak hívott tehát lehet szükíteni.

- Re-familization ${ }^{7}$ (Hoffmann és mtsai, 2013) and de-intitutionalization ${ }^{8}$ (Rose, 2015). A család gondozó szerepének újragondolása nemcsak a nemzetközi szervezetek elvei között jelent meg. Többek szerint a kelet európai országok fenntartható idősgondozásának egyedüli esélye, ha a családi gondozás felé mozdulnak el. A családi gondozást erősítő mozgalmak azonban szinte minden tagállamban megjelentek, igaz más - más háttérrel. Például Svédország is komolyan foglalkozik a családi gondozás erösítésével, míg más országokban a népesség összetételének változása (bevándorlók magas száma és öregedése, akik nem veszik igénybe az állami - egyházi intézményeket Hollandiában) következtében mozdultak el ebbe az irányba. Az intézménytelenítés ideológiája az időskorú intézményi izolációjának csökkentése és a gondozás közösségbe ágyazása, a feladatok megosztása mentén kialakult ideológia, mely nem nélkülözi a költséghatékonyság értékeit sem. A család gondozó szerepének priorizálása szempontjából lényegi megközelítés az ún. explicit familialism (Leiter, 2003) mely szerint progresszív ösztönző támogatásokkal és szolgáltatásokkal lehet támogatni a

\footnotetext{
${ }^{4}$ A család szerepét csökkentő, családot tehermentesítő politikákat szokás ezen a néven említeni. Magyar megfelelője nincsen.

${ }^{5}$ Gondozási támogatás, melyet maga az időskorú kap meg, így nagyobb szerepe van a saját gondozásának megtervezésében. Az ellátást kvázi megvásárolja a szolgáltatóktól, akik ezért versengenek érte.

6 cottage industry - azon szolgáltatások és javak, melyeket könnyen helyettesíteni lehet a család szerepvállalásával, így az állam szerepe és felelőssége csökkenthető.

${ }^{7}$ Családi szerepvállalás erősítése az idősek gondozásában

${ }^{8}$ Intézménytelenítés
} 
családi gondozást. Michon (2008) szerint azonban több államban inkább az un. negatív familizáció jellemzőit észlelhetjük, azaz a család növekvő szerepe kisebb állami szerepvállalással és minimális családtámogató eszközökkel valósul meg.

- A migráns gondozás támogatása. A migránsok által végzett gondozásnak igen széles irodalma van a fejlett jóléti államokban. A fő diskurzusok között a migráns gondozás legalizálása (pl. Ausztria), a gondozók kiszolgáltatott helyzete, valamint a gondozó és gondozott kapcsolat minősége szokott állni. A mi olvasatunkban azonban a kérdés inkább az, hogy a gondozó munkaerőt kieresztő országokban milyen problémákat okoz a gondozó munka kiáramlása. A kelet európai gondozási célú migrációt körkörös (Gendera, 2011), vagy befejezetlen (Okólski, 2001) migrációnak nevezik, mely arra utal, hogy a munkaerő többször hosszabb időre vándorol ki, majd tér vissza. A kiáramló gondozók sajátos helyzetet generálnak - sok esetben arra késztetve az anyaországot, hogy nagyobb feladatot vállaljon az időskorú gondozásában. Azt azonban nem szabad hinni, hogy a migráns gondozók alkalmazása nem érinti a keleti országokat (Okólski, 2001) (Széman, 2012).

\section{Kelet - Európai országok családi gondozást támogató rendszerei}

Sajnálatos módon kevés olyan kutatás áll rendelkezésre, mely megfelelő adatokkal tudná alátámasztani a Kelet - Európai országokban zajló folyamatokat. Az összehasonlító kutatások gyakran a gondozási rezsim típusok szerint közelítenek (Lamura és mtsai, 2008) ami arra enged következtetni, hogy a kiválasztott ország reprezentálja az összes többit. Ez azonban nem biztos, hogy így igaz. Az utóbbi időkben a gondozáspolitika ezekben az amúgy is nehezen tipizálható jóléti rezsimekben gyorsan változik, s bizonyos esetekben egyszerre fedezhetünk fel egymásnak ellentmondó folyamatokat is.

A kutatások általában véve leszögezik a formális ellátások fejletlenségét, kiemelik az egészségügyi és szociális long term care rendszerek széttagoltságát, illetve az ebből fakadó problémákat. A gondozáshoz kötődő táppénz juttatás (care leave) bizonyos esetekben kedvezőbb feltételeket mutat, mint a liberális, vagy a care mix országokban, de a juttatások mértéke igen alacsony, vagy nincs is (fizetés nélküli szabadság). Egy tanulmány például kiemeli Lengyelországot, ahol a gondozók táppénz ellátásra számíthatnak a gondozás során (Lamura és mtsai, 2008). A gondozásra szorulás szükséglete miatti támogatások (pl. ápolási díj) bizonytalanok és általában véve alacsony szintűek, nem ösztönöznek a munkaerőpiacról való kilépésre. Vállalásuk pedig a háztartás elszegényedésének kockázatával és a gondozó későbbi munkanélküliségének kockázatával jár. Több országban elsősorban a fogyatékos, és a 
gyermekek neveléséhez kapcsolódó támogatások az elterjedtebbek, s csak néhol találni idősek gondozása esetén adható támogatást (pl. Szlovákia). Bizonyos jelentések Magyarország igen bőkezü családtámogató rendszereit emelik ki jó példaként, de tudni illik, hogy ezek a támogatások a gyermekek neveléséhez kötődnek és nem az idősek gondozásához.

Szlovéniában a munkaerőpiacot elhagyó gondozónak jár gondozási támogatás, illetve lehetőség van részmunkaidőt vállalni a gondozás mellett, ez esetben a támogatás a minimálbérig egészíti ki a gondozó bérét (Hlebec, 2015). A formális ellátás igénylésének egyik indikátora, hogy a család nem tudja gondozni az időst, vagy tudná, de túl messze élnek tőle.

A családi szerepvállalást erősítő és csökkentő politikák tekintetében is eltérő irányokat lehet látni. Csehország néhány éve vezette be a cash-for-care rendszert, mely a család gondozói szerepét erősítheti, de mellette elköteleződött az intézményes szolgáltatások fejlesztése mellett is (Greenwood, 2016). Erre azért volt szükség, mert a cash benefits nem segítette a vidéken, egyedül élő nagyon idősek megfelelő gondozását.

E kettős hatás Magyarországon is érvényesül igaz más okokból, mint majd látjuk később.

A gondozási támogatások elérhetősége és mértéke tekintetében Piotr Michon végzett összehasonlító elemzést (2008). Az általa használt klasszfikáció három fô csoportra bontotta a vizsgált országokat. A „megfelelő” az ahol a család támogatása és a szolgáltatások biztosítása is magas szintü. Ebbe a csoportba a posztkommunista országok közül Szlovákiát helyezte. A „szubszidiarista” esetében a családra épülő politika erős, a szolgáltatások magas szintűek és nem kell sokat fizetni értük. Ide sorolta Magyarországot is, de ahogy jeleztem ez a gyermekek gondozására irányul, nem az idősekére. a „semleges” rendszerben valamilyen szintű családi támogatás létezik ugyan, de e mellett kevés szolgáltatást lehet elérni. Ide sorolta Lengyelországot a szerző.

\section{Gondozó családot támogató politika Magyarországon}

A rendszerváltás után kialakuló szociális ellátási és szolgáltatási rendszer alapjában institucionalista értékek szerint igyekezett az idősek tartós gondozását ellátni. Ez jellemzően a bentlakásos ellátások müködtetését, bizonyos esetekben a férőhelyek fejlesztését jelentette. A Szociális törvény hatálybalépése után tíz évvel 2004-ben már nyilvánvaló volt az otthoni szolgáltatások fejletlensége a bentlakásoshoz képest, így a szolgáltatásfejlesztés új iránya az idősek otthoni gondozásának támogatása lett. Valójában a reformot követő években is folyamatosan nőtt a bentlakásos férőhelyek száma, majd különböző szolgáltatáspolitikai stratégiák hatására - melyek kifejtésére e tanulmány keretei szűkösek - dinamikusan nőtt az otthoni formális gondozásban részesülők száma is. 
Az informális gondozást támogató politikák elemzésével foglalkozó kutatások (Triantafillou és mtsai, 2010) szerint a Közép - Kelet Európai országokra a családot támogató támogatások és szolgáltatások alacsony színvonala jellemző. A családtagokat nem segítik szolgáltatásokkal, a formális rendszer sok esetben egyszerüen nem veszi figyelembe jelenlétüket. Ha a gondozás során mégis sor kerül az informális és formális gondozó találkozására, akkor is az időskorú szükségleteinek kielégítése kerül a formális gondozás középpontjába. A gondozónak járó támogatási formák általában alacsony összegüek. A legtöbb esetben nem a „gondozás” képezi a jogosultság alapját, hanem a gondozás miatti jövedelem kiesés, így a támogatás (pl. ápolási díj) alacsony összegü, jövedelem helyettesítő funkciójú, azaz a nem munkaképes korú lakosság eleve nem részesülhet benne.

A formális rendszerek fejlesztése a bentlakásos ellátások esetében a szolgáltatás minőségi fejlesztését és az ellátás specializálódását is jelentette, míg a házi segítségnyújtás esetében a rapid kapacitásnövelés inkább az ellátás túlterhelődéséhez vezetett.

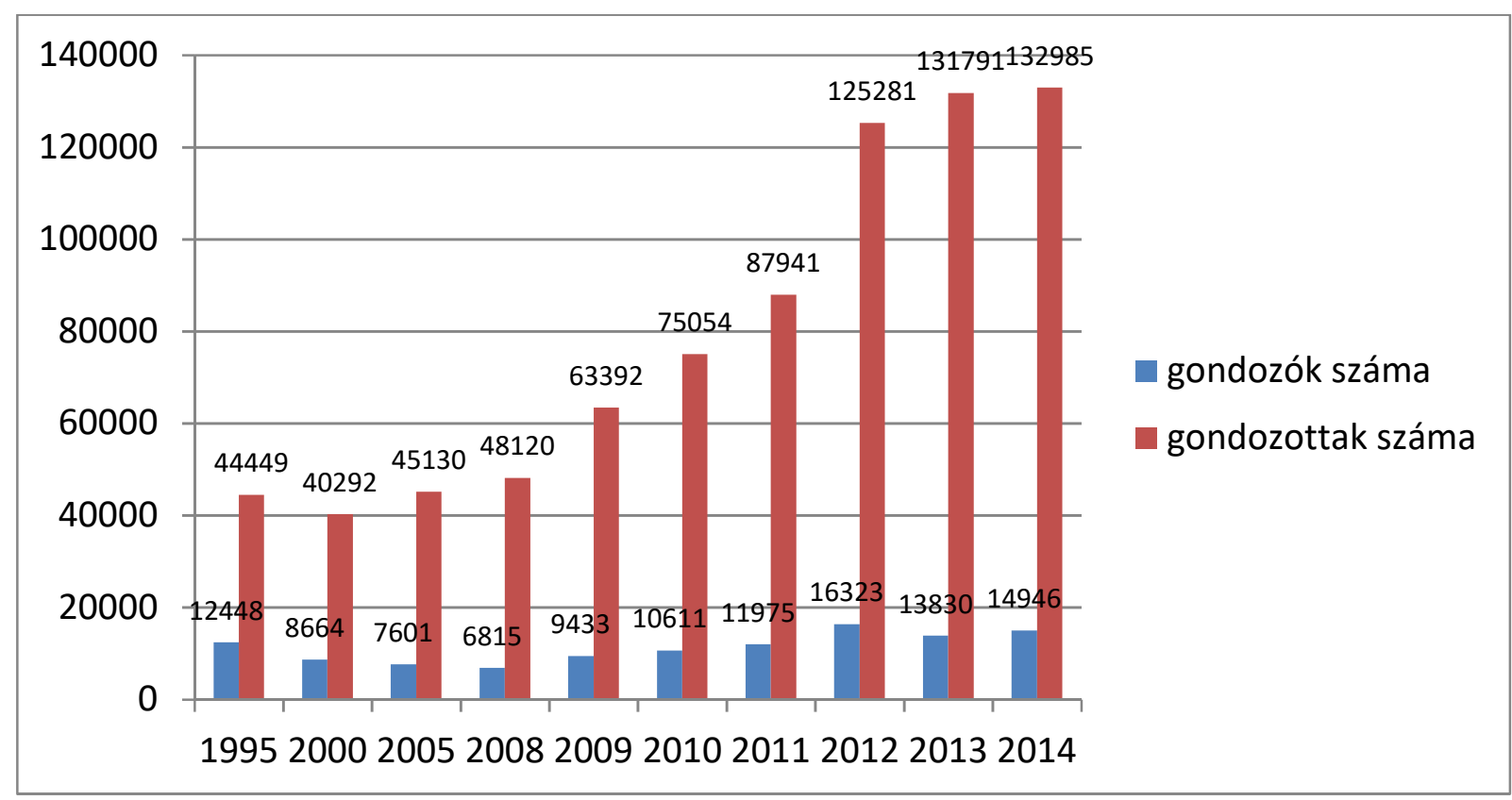

1. ábra. A gondozók és gondozottaik száma a házi segítségnyújtás szolgáltatásban Magyarországon (KSH, 2014)

A szabályozás anomáliái miatt ellátás egyre megterhelőbbé vált a szakemberek számára, ami oda vezetett, hogy a gondozók és a fenntartók előnyben részesítették az alacsonyabb gondozási szükséglettel rendelkező időseket. A gondozás jobban koncentrált a fizikai gondozásra és háttérbe szorult a lelki gondozás jelentősége. Ez a folyamat önmagában tehát nem tehermentesítette a családtagokat, sőt ott kellett a családnak komolyabb szerepet vállalnia, ahol az idős intenzívebb gondozást igényelt. 
A keresztény - konzervatív kormányzat első lépése volt a szülőtartás kötelezettségének Alaptörvényben való rögzítése (Magyarország Alaptörvénye, 2011 XVI. Cikk. (4). ${ }^{9}$ ) mely után sejthető volt egy erőteljesebb családi gondozást támogató politika kidolgozása. ${ }^{10}$ Ezzel szemben azonban egy erős etatista és centralizáló szociálpolitika alapjait rakta le a kormány, mely megnyirbálta az önkormányzatok autonómiáját, központosította a bentlakásos ellátások jó részét és drasztikusan csökkentette a segélyeket is. A gondozó családtagok számára elérhető támogatás a méltányossági ápolási díj volt. A támogatás mértéke igen alacsony volt, 2014-ben 24.450 HuFt ami az akkori minimum jövedelem negyede. A támogatott időszak beszámított a járulékfizetési időbe, tehát nyugdíjjogosultságot generált. A támogatást csak aktív korúak vehették igénybe, s mellette részmunkaidőben lehetett dolgozni is. Azokat az időseket, akik idős társaikat gondozták tehát eleve kizárta a rendszer. A kormány 2014-ben megszüntette az időskorút ellátó családi gondozók egyetlen ellátását, a méltányossági ápolási díjat. A támogatást ettől kezdve az önkormányzatok adhatják, települési támogatás formájában. Statisztikai adatok híján az sejthető, hogy a rosszabb anyagi helyzetben lévő kisebb települések nem éltek a méltányossági szabályozás lehetőségével.

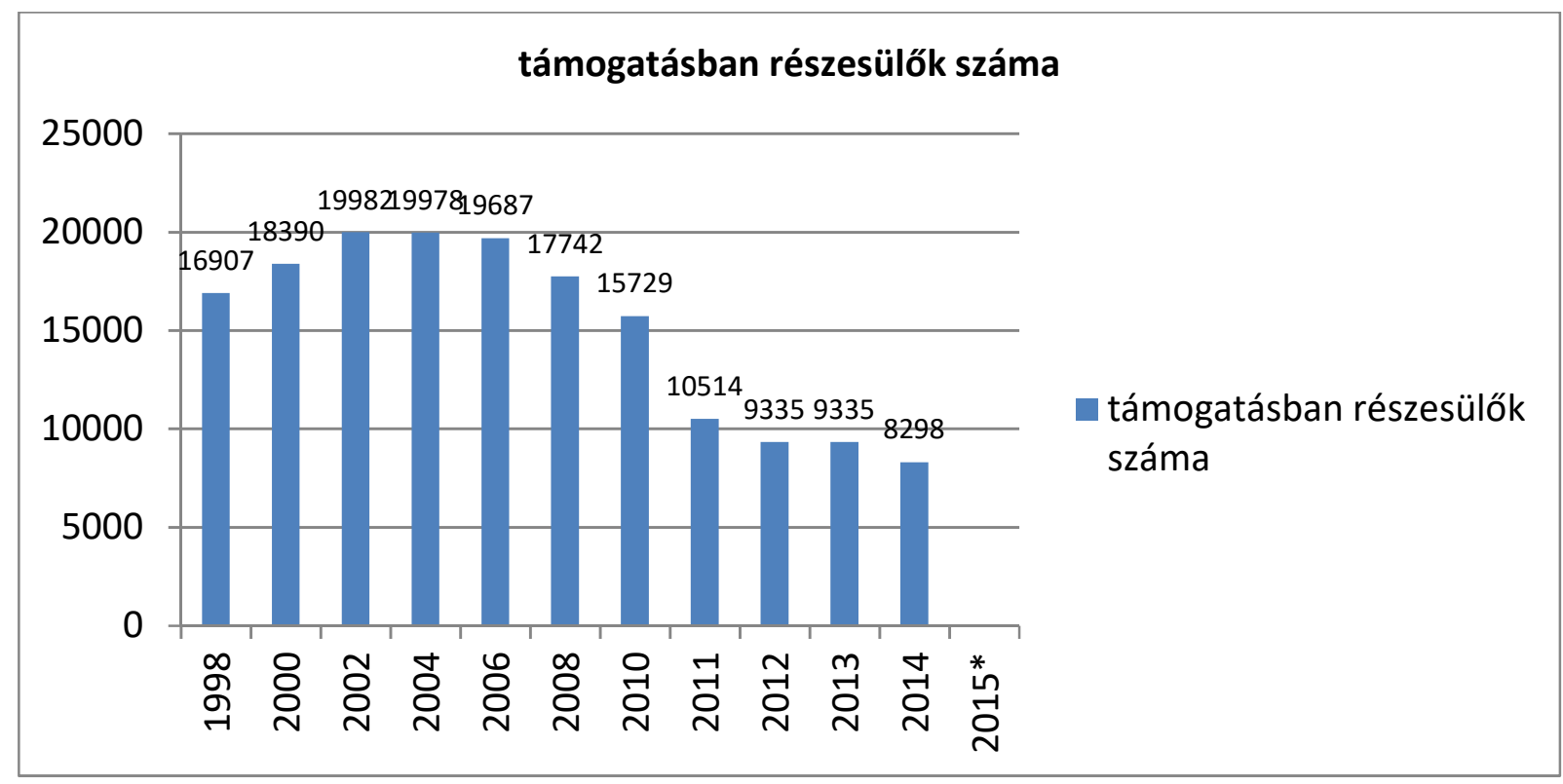

2. ábra. Méltányossági ápolási díjban részesülők száma Magyarországon (Forrás: KSH, 2015)

*Nincsen rendelkezésre álló adat a méltányossági ápolási díjról.

Magyarországon nem lehet táppénzt igénybe venni az idős hozzátartozó gondozásának idejére.

\footnotetext{
9 „A nagykorú gyermekek kötelesek rászoruló szüleikröl gondoskodni”

${ }^{10}$ Megjegyezzük, hogy e kötelezettség már korábban is joganyagba volt foglalva (1952 évi IV. tv. A házasságról, családról és gyámságról)
} 
Fizetés nélküli szabadság alanyi jogon igényelhető a hozzátartozó gondozására maximum két évig. A fizetés nélküli szabadság intézményével azonban csak nagyon kevesen élnek, hiszen a család megélhetését veszélyeztetnék az időskorú gondozása okán. A gondozók jelentős része az ún. ,pivot” (szendvics) generációba tartozó, ötvenes éveiben lévő nő, akiknek gyermekeiket éppúgy kell támogatniuk, mint szüleiket gondozniuk.

A gondozó családtag támogatásával kapcsolatos restriktív folyamatok egy része nem direktív (közigazgatás centralizációja miatt kialakult új szabályozás) más részük a munka alapú társadalomba vetett hit miatt hozza hátrányos helyzetbe a családtagot gondozókat. Érdekesség, hogy e tekintetben a hazai szakpolitika kifejezetten érzéketlen az idősek helyzetére, mivel a fogyatékos személyeket gondozók számára továbbra is fenntartja az ápolás támogatását ${ }^{11} . \mathrm{Az}$ idősek családi gondozására még rátapad egy további elöítélet is, mely szerint ezt a tevékenységet azok végzik, akik nem akarnak a munkaerőpiacon elhelyezkedni, munkából, jövedelemből megélni.

A gondozó családtagok támogatását elemző kutatások mind rámutatnak a családtagok kiemelkedő terheire, a gondozás anyagi kockázataira, a munkaerőpiacról való kiszorulás kockázatára és kiemelik, hogy a családi gondozás az idősek megfelelő és fenntartható gondozásának egyik nagyon fontos eleme. Mindezek ellenére a családi felelősségvállalás Magyarországon inkább az ellátás költségeinek viselését jelenti, hisz a valós gondozás vállalásához az állam nem nyújt megfelelő támogatási lehetőségeket. Nem érzékeny a rendszer a kritikus helyzetekre (pl. idősek gondozzák egymást) és nem kezeli a szociális rászorultság kérdését sem, így azok, akik nem tudják megfizetni az állami, vagy magán ellátásokat és maguk gondozzák családtagjaikat súlyos anyagi hátrányokkal kell, hogy szembenézzenek. Az implicit familialism (Leiter, 2003), vagy a negatív familizáció Michon (2008) fogalmai pontosan ezt a szelektáló, kirekesztő, az állami felelősséget a család felé toló gyakorlatot igyekeztek bemutatni.

\section{Irodalomjegyzék}

1. Brigit Pfau-Effinger(2014): New policies for caring family members in European welfare states, Cuaderos de Relaciones Laborales 2014. Vol. 32. 33 - 48. ISSN: 1131-8635

2. Denis Bouget, Llaniva Spasova, Bart Vanhercke (2016): Work-life balance mesures for persons of working age with dependent relatives in Europe European Comission

\footnotetext{
${ }^{11}$ Nyilván itt egy élethosszig tartó gondozási tevékenységről van szó.
} 
3. Frédérique Hoffmann, Manfred Huber and Ricardo Rodrigues(2013): Policies to support carers in. A. Moreno Minguez (ed): Family Well-Being: European Perspectives; Springer Science Business Media 2013. (pp. 243 - 260.)

4. Hajek, André - König, Hans - Helmut (2015): Informal Caregiving and Subjective WellBeing: Evidence of a Population Based Longitudinal Study on Older Adults in Germany, JAMDA, 1 - 6. Elsevier

5. Help wanted? Providing and Paying for Long Term Care Chapter 4. Policies to Support Family Carers, OECD 2011. 121 - 158.o

6. Herrmann F. R. - Michel J. P. - Robine J. M. (2010): Worldwide Decline of the Oldest Old Support Ratio European Geriatric Medicine, Vol. 1, Issue 1. p. 3 - 8.

7. Gendera Sandra (2011): Gaining an insight into Central European transnational care spaces: Migrant live in care in Austria. in: Foggy Social Structures Irregular Migration, European Labour Markets and the Welfare State eds: Michael Bommes - Giuseppe Sciortino Amsterdam University Press, 2011. p. 91 - 116.

8. Giovanni Lamura, Eva Mnich, Mike Nolah, Beata Wijszel, Barbro Krevers, Liz Mestheneos, Hammeli Döhner(2008): Family Carer's Experiences Using Support Service sin Eurpoe: Empirical Evidence From the EUROFAMCARE Study The Gerontologist, 48. 6. p. $752-771$.

9. Greenwood, Nan - Holley, Jess - Theresa Ellmers - Gill Mein - Geoffrye Cloud (2016): Qualitative Focus Group Study Investigating Experiences of Accessing and Engaging with Social Care Services: perspectives of carers from diverse ethnic groups caring for stroke survivors BMJ. Open, January, 2016.

10. Gosta Esping Andresen (1990): The Three Worlds of Welfare Capitalism Princeton University Press, New Jersey

11. KATHARINE Schulmann, KAI Leichsenring, GEORGINA Casanova, VALISIA Ciuca, LARCAMIOARA Corches, MIHAELA Genta, ZANA Grigaliüniené, CSABA Kucsera, ANIELA Matei, NIKU Maattanen, GERARD Naegele, GERLI Paat-Ahi, SPERANTA Pirciog, ANDREA Principi, LEONOR Rodrigues, RICHARDO Rodrigues, BERTHA Sanduleasa, SANDRA Shulze, MONIKA Reichert, ZSUZSA Szeman, KARIN Wall (2012): MoPAct Mobilising the Potential of Actine Ageing in Europe Social support and long term care in EU care regimes WP8. Overview report www.mopact.group.shef.ac.uk

12. Laura Hiel - Marielle A. Beenackers - Carry M. Renders - Suzan J. W. Robroek - Alex Burdorf - Simone Croezen (2015): Providing personal informal care to older European 
adults: Should we care about the caregirers' health? Preventive Medicine, 70. $64-68$. Elsevier

13. Lamura, G., Mnich, E., Bień, B., Krevers, B., McKee, K., \& Mestheneos, L., et al (2007, July). Dimensions of future social service provision in the ageing societies of Europe. Keynote lecture presented at the VI European Congress of the International Association of Gerontology and Geriatrics, St. Petersburg, Russia.

14. Okólski, M (2001): Incomplete migration: A new form of mobility in Central and Eastern Europe. The case of Polish and Ukrainian Migrants. in: C. Wallace - D. Stoda (eds.) Patterns of migration in Central Europe Houndmills: Palgrave Publishers p. 105 - 128.

15. Piort Michon (2008): Familization and defamilization policies in 22 European countries. Poznan University of Economics Review 2008/8.N.1. 34 - 54.

16. Tausz Katalin (2006): A jóléti állam és Magyarország = The Welfare State and Hungary. in: Vizi E. Szilveszter - Teplán István - Szentpéteri József (szerk.): Előmunkálatok a társadalmi párbeszédhez. Gazdasági és Szociális Tanács, Budapest, 149-159.

17. Triantafillou, Judy - Naiditch, Michel - Repkova, Kvetoslava - Stierh, Karin - Carretero, Stephanie - Emmilson, Thomas - Di Santo, Patrizia - Bednerik, Rastislav - Brichtova, Lidia - Ceruzzi, Francesca - Cordero, Laura - Mastroyiannakis, Tasos - Ferrando, Maite - Mingot, Karl - Ritter, Joachim - Vlantori, Diamantoula(2010): Informal care in the Long Term Care system Wienna/Athens Funded by the INTERLINKS project.

18. Tyen Tsai (2010): More Caregivers Needed Worldvide for the 'Olders Old' Population Reference Bureau http://www.prb.org/Publications/Articles/2010/oldestold2050.aspx

19. Valentina Hlebec (2015): Care arrangements among social home care users in Slovenia, Studia Socioloczne 2015, 2. 75 - 96 ISSN 0039-3371

20. Zsuzsa Szeman (2012) Family Strategies in Hungary: the Role of Undocumented Migrants in Eldercare JOURNAL OF POPULATION AGEING 5: (2) pp. 97-118.

Patyán László főiskolai docens

Debreceni Egyetem Egészségügyi Kar

Gerontológia Tanszék 4400 Nyíregyháza, Sóstói u. 2-4.

tel: 36-70-366-5744, mail: patyan.laszlo@foh.unideb.hu 